\title{
Acumulação de Vencimentos e Proventos
}

\section{HOMERO FREIRE}

I - E' permitido acumular proventos decorrentes de aposentadoriaprêmio (inciso II do art. 176 da lei federal n. ${ }^{\circ} 1.713$, de 1952 , e $\S 1 .^{\circ}$ do artigo 191 da Constituição Federal), com vencimentos de outro cargo?

Em outras palavras: pode o funcionário aposentado em face de contar 35 anos de serviço, exercer outro cargo, acumulando, assim, os proventos do antigo com os vencimentos do novo cargo?

II - Da leitura que pudemos fazer sôbre o assunto, do que escreveram os juízes e disseram as leis, parece-nos que a resposta deve ser positiva: pode!

O grande PEDRO LESSA fazia repousar sua opinião em contráriơ no motivo de que

"Se o legislador proibiu ao indivíduo válido acumular o exercício de dois cargos remunerados, como havia de tolerar que o inválido, o incapaz de trabalhar, o inapto para o exercício de funções públicas, além de perceber a sua aposentadoria. ainda receba vencimentos pelo exercício ilegal de um cargo que não podia ocupar?" (Voto vencedor no acórdão do Supremo Tribunal Federal, de 27-7-1914, in "Revista do Supremo Tribunal Federal", vol. 2. ${ }^{\circ}$, pág. 220, e vol. 25, pág. 80 , citado Temístocles B. Cavalcanti, no seu "Tratado de Direito Administrativo", vol. III, pág. 305).

Acêrca de dispositivo da Carta de 1937, relacionado com a matéria, o Ministro da Justiça manifestou o pensamento de que o mesmo visou

"impedir que um funcionário considerado inválido ou incapaz para o exercício de uma função pública e por êste motivo dela afastado, com proventos, seja considerado capaz para o exercício de outra e por êste exercício venha a perceber remuneração" ("Revista do Serviço Público", anơ I, vol. II, página 53).

A. legislação veda "a acumulação de quaisquer caróos" (art. 185 do Constituição Federal e art. 188 do Estatutơ dos Funcionários Públicos Civis da Uniăo, lei n. ${ }^{0} 1.713$, de 1952) (grifo nosso), mas não proibe a de proventos de aposentadoria-prêmio com vencimentos de cargo. Aqui não há acumulação "de cargos", objeto da proibição. 
III - Afigura-se-nos destituído de boas razões e incompatibilizado com os princípios de hermenêutica constitucional, data venia, o argumento esgrimido pelo eminente Ministro Henrique d'Ávila, com o beneplácito da maioria dos membros do Tribunal Federal de Recursos, de que

"... os proventos da aposentadoria se equiparam a vencimentos... para efeito da proibição constitucional" (Voto vencedor no Acórdão de 17-4-52, no Mandado de Segurança número 1.532 , in "Revista Forense", vol. 146, págs. 203-206).

Essa equiparação não consta da Constituiçãa, e nem é possível extrai-la du preceituado no art. 185.

Se o estatuto fundamental claramente define a hipótese da vedação exercício simultâneo de mais de um cargo; - se a passagem constitucional atém-se ao problema da acumulação das tarefas cometidas a dois ou mais cargos, sem aludir, sem preocupar-se, sem apontar a questão, inteiramente estranha, do auferimento de duas remunerações - proventos e vencimentos, - não nos parece admissível, interpretando, alongar a aplicação do dispositivo para sujeitar outra hipótese não referida, ao crivo da proibição: seria cutorgar ao intérprete o poder de aduzir condições novas não previstas na lei e não querida pelo legislador no sentido de estender a outros casos a oposição. A preocupação do legislador constituinte fixou-se no plano físico e não no econômico; o propósito foi evitar a dispersão de esforços para assegurar o bom rendimento do serviço, o que nenhuma implicação guarda com o problema da remuneração.

Daí que achamos insólito equiparar proventos com vencimentos para efeito de estender também insòlitamente a proibição da acumulação de cargos, única prevista na vedação constitucional, à proibição da acumulação de remuneração, que não prendeu a atenção do legislador.

Correto, a nosso fraco entender, o pensamento exposto no voto vencido do eminente Ministro Cunha Vasconcelos, quando argumenta que

"Falando em cargos, o constituinte definiu seu intento e não há que confundir proventos de aposentadoria com cargos".

E mais de espaço:

"Pergunto: proventos de aposentadoria pode ser havido como cargo? Não. Cargo significa proventos de aposentadoria? Não".

E dá o quid do problema:

"Não se está vendo, aí, que a Constituição, que defende o maior rendimento do serviço a que se deve entregar o cidadão, quando permite a acumulação, em casos especiais, exigindo correlação de matérias e compatibilidade de horário, está pondo a nu o intuito determinante do dispositivo?" (local citado, pág. 205). 
Realmente, o de que cogitou a Constituição foi assegurar o maior rendimento do serviço, obrigando ao funcionário só se dedicar à tarefa de um cargo, ou, excepcionalmente, de mais de um quando haja correlação de matérias e compatibilidade de horários: a correlação de matéria porque não desvia o interêsse intelectual do servidor para outro mister, $\sigma$ que possibilitaria a dispersão de esforços e impediria o aprimoramento da especialização; a compatibilidade de horários porque, da mesma forma e por outro caminho, só assim poderá o servidor dedicar-se inteiramente às duas funções em expedientes próprios, sem o prejuízo de uma pela outra.

$\mathrm{E}$ em nenhuma ocasião do trabalho legislativo interessou ao legislador a questão do ganho, da vantagem econômica.

IV - Contudo, precisamente pelo fato de o impedimento de acumular carǵos resultar da necessidade de preservar o rendimento do serviço, precisamente por isso é que cabe estabelecer uma distinção que o brilhante voto vencido não fêz, mas que é imprescindível fazer.

Se, em tese, não há confundir acumulação de cargos com recebimento simultâneo de remuneração (proventos e vencimentos), há casos em que a aposentadoria impede, de modo absoluto, $\alpha$ inativo de exercer novo cargo.

Referimo-nos à inatividade motivada por incapacidade laborativa ou mesmo por implemento de idade, que configura uma invalidez presumida.

Exatamente em atenção a êstes casos foi que o voto de Pedro Lessa e o parecer ministerial antes referidos, proclamaram, com razão, a impossibilidade de o funcionário aposentado exercer outro cargo.

E' lógico: se o servidor foi considerado inválido, incapaz de trabalhar, tanto que mereceu sua aposentação, não se compreende que, contraditòriamente, seja nomeado para o exercício de outro cargo, cujo pressuposto legal, além de outros, é justamente o de "gozar de boa saúde" (inciso VI do art. 22 do Estatuto dos Funcionários Públicos Civis da União).

Das duas uma: ou êle continua inútil para o serviço, e então não pode exercer mais cargo público pela ausência de "boa saúde" necessária à posse e exercício, ou readquiriu a capacidade de trabalho, e então o caminho a seguir é decretar-se a reversão ao cargo ocupado à época da aposentadoria (artigo 68 do Estatuto); e, efetuada a reversão, reaparece a proibição da acumulação, impedindo o exercício de outro cargo.

Distinta não é a conclusão em se tratando de inatividade por implemento de idəde: a presunção absoluta de invalidez que atinge o funcionário septuagenário, incidirá em relação a qualquer cargo, impossibilitando-o de acumular proventos e vencimentos.

Como se vê, tudo isso diz com a impossibilidade física do exercício da função; na acumulação de carǵos em face da dispersão de esforços e incompatibilidade de horários, no caso das aposentadorias por invalidez e implemento de idade, pela incapacidade laborativa que atinge o funcionário.

Ainda aqui ausente se encontra o problema econômico da acumulação de remuneração, que não influi no deslinde do assunto. 
V - Ora, não padece do mesmo motivo de impedimento físico, a hipótese de aposentadoria-prêmio. Aqui não estamos diante de um funcionário julgado inválido, e, portanto, incapaz de exercer qualquer outro cargo, mas de servidor que, contando 35 anos de serviço, sem embargo de sua higidez, de sua capacidarie de trabalho, faz valer o direito subjetivo à isenção de serviço com recebimento de proventos iguais aos vencimentos; na espécie, a lei instituiu um prêmio, uma vantagem especial que não exclui a capacidade laborativa, antes a pressupõe, porque, se inapto o funcionário, a aposentação se processaria por êsse motivo de invalidez.

Útil ao serviço, apenas no gôzo de uma aposentadoria-prêmio, nada impede a nomeação do inativo dessa espécie para outro cargo, por isso mesmo que, como fizemo's ver, a vedação constitucional incide sôbre a acumulação de carǵos, e não acumula cargos quem sòmente exerce um, apesar de auferir proventos de outro. Inativo em relação ao cargo que antes da aposentadoria exercia, o funcionário dispõe de todo o tempo e de tôda sua atividade física e intelectual para o regular exercício do novo cargo, afastando a razão de política administrativa que desaconselha a acumulação.

Ainda que geralmente se reconheça a relação entre a administração pública e as outras fases complementares do Estado, é todavia muito tímida a disposição para apreciar os processos administrativos do govêrno como uma expressão da cultura de cada povo. Por certo, a administração pública, tanto no poder executivo como nos demais setores do govêrno, é um reflexo do estilo de vida de cada sociedade de sua configuração de idéias, atitudes, costumes, normas, instituições, processos e outras formas de conduta.

Pedro Muños Amato, Introdução à Teoria Geral de Administração Pública, Cadernos de Administração Pública, E.B.A.P. 